\title{
Spatial Pattern Analysis of Malaria Cases in Muara Enim Regency using Moran Index and Local Indicator Spatial Autocorrelation
}

\author{
Elvi Sunarsih ${ }^{1} *$ (D) , Muhammad Zulkarnain ${ }^{2}$, Laila Hanum ${ }^{3}$, Rostika Flora ${ }^{1}$ D, Nurhayati Damiri ${ }^{4}$ \\ ${ }^{1}$ Environmental Science Study Program, Sriwijaya University, Palembang, Indonesia; ${ }^{2}$ Department of Public Health Science, \\ Faculty of Medicine, Sriwijaya University, Palembang, Indonesia; ${ }^{3}$ Department of Biology, Faculty of Mathematics and Natural \\ Sciences, Sriwijaya University, Palembang, Indonesia; ${ }^{4}$ Public Health Science Study Program, Faculty of Public Health, \\ Sriwijaya University, Palembang, Indonesia
}

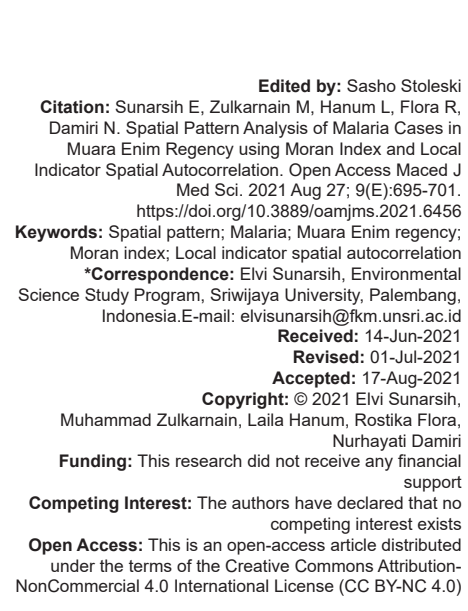

\section{Introduction}

Malaria still becomes a world health issue, including in Indonesia, due to its potential vector that can transmit and spread causing a wide impact. In addition, malaria is a disease in remote or difficult to reach areas and in poor or developing countries so that it becomes a priority target for global commitments in the Millennium Development Goals (Research and Development Agency of the Republic of Indonesia, 2010) [1].

Malaria is generally transmitted through female Anopheles mosquito bites which suck blood for its egg growth. Anopheles commonly bites actively at night. In several past years, malaria outbreaks have reoccurred in several malaria-endemic areas in Indonesia. The increasing number of malaria cases is still affected by climate change factors related to the physical, chemical, biological, and social environment as well as community behavior [2]

There have been 80 species of Anopheles mosquitoes found in Indonesia, 20 of them can act as malaria vectors, including Anopheles aconitus, Anopheles sundaicus, Anopheles subpictus, Anopheles maculatus, Anopheles barbirostris, Anopheles balacencis, Anopheles punctulatus, Anopheles kochi, Anopheles koliensis, Anopheles minimus, Anopheles nigerrimus, Anopheles sinensis, Anopheles flavirostris, Anopheles tessellatus, Anopheles bancrofti, Anopheles karwari, Anopheles letifer, Anopheles ludlowae, and Anopheles umbrosus [3].

Furthermore, 36,201 clinical malaria cases were found in 2015 in South Sumatra Province. The second highest positive malaria case in South Sumatra Province was in Muara Enim District with an API value in 2019 of $0.18 / 1000$ population (Health Department of South Sumatra Province, 2019). Data on malaria 
cases, environment, and behavior were obtained from primary and secondary data. The data were further analyzed descriptively against environmental data. The distribution of malaria cases was carried out by mapping and spatial analysis (GIS) in which the data analysis was done through spatial analysis with weighting and scoring [4].

Spatial analysis is a statistical method that includes elements of area/space in its analysis. One of the spatial statistical methods used to determine the dependence of one region on another is Moran's index. Moran's index analyzes an attribute based on several regions, while to determine the dependence of each region, Moran's local or local indicator spatial autocorrelation (LISA) is used. Through the LISA method, we can find out the dependence of each region, while the Moran's index is general [5].

\section{Methods}

This research was carried out quantitatively through analytical survey research method and a case-control approach. This research method was designed using a geographic information system approach through secondary data collection activities consisting of data on malaria cases in Muara Enim Regency in 2017-2019, habitat map data (shrubs, lakes, ponds, forests, gardens, swamps, and farms) and environment (rainfall), population density data, land use data, and altitude data. The research was done in Muara Enim Regency using various tools and materials, such as one set of stationery, one set of questionnaires, one camera unit (HP/Digital), and secondary data. The population involved in this study was all malaria cases in Muara Enim Regency area recorded in the recording and reporting of malaria from Muara Enim Health Office in 2017-2019. The sampling technique used was Classified Proportional Random Sampling method, using the multistage sampling technique or gradual sampling.
Data analysis was carried out using spatial analysis and spatial patterns of research data [6], [7], [8].

\section{Results}

\section{Spatial pattern analysis of malaria cases in} Muara Enim Regency using Moran index and LISA

Results of spatial pattern identification and analysis of malaria cases in 2017-2019 in Muara Enim Regency using Moran index and LISA are shown in the following figure:

Based on Figure 1, it is known that there are three districts categorized as high-high $(\mathrm{HH})$ (quadrant 1) in 2017. Those districts are Lawang Kidul, Muara Enim, and Gunung Megang Districts. Meanwhile, district belongs to low-low (LL) category (quadrant 3) are Lembak and Gelumbang Districts. Furthermore, district belongs to low-high ( $\mathrm{LH}$ ) category (quadrant 2) is Benakat District.

In 2018, district belongs to $\mathrm{HH}$ category (quadrant 1) was only Lawang Kidul District, while district belongs to LH category (quadrant 2) is Gunung Megang District.

In 2019, district categorized as $\mathrm{HH}$ (quadrant 1) is Lawang Kidul District, while those belong to the $\mathrm{LH}$ category (quadrant 2) are Semende Darat Laut and Rambang Niru Districts.

Based on Figure 2, Moran index value is 0.263 , indicating that there was a positive autocorrelation, which means that malaria cases in Muara Enim Regency in 2017 occurred in groups.

Based on Figure 3, the Moran index value is 0.129 , indicating that there is a positive autocorrelation, which means that malaria cases in Muara Enim Regency in 2018 occurred in groups.

Based on Figure 4, the Moran index value is -0.022 , indicating that there is a negative

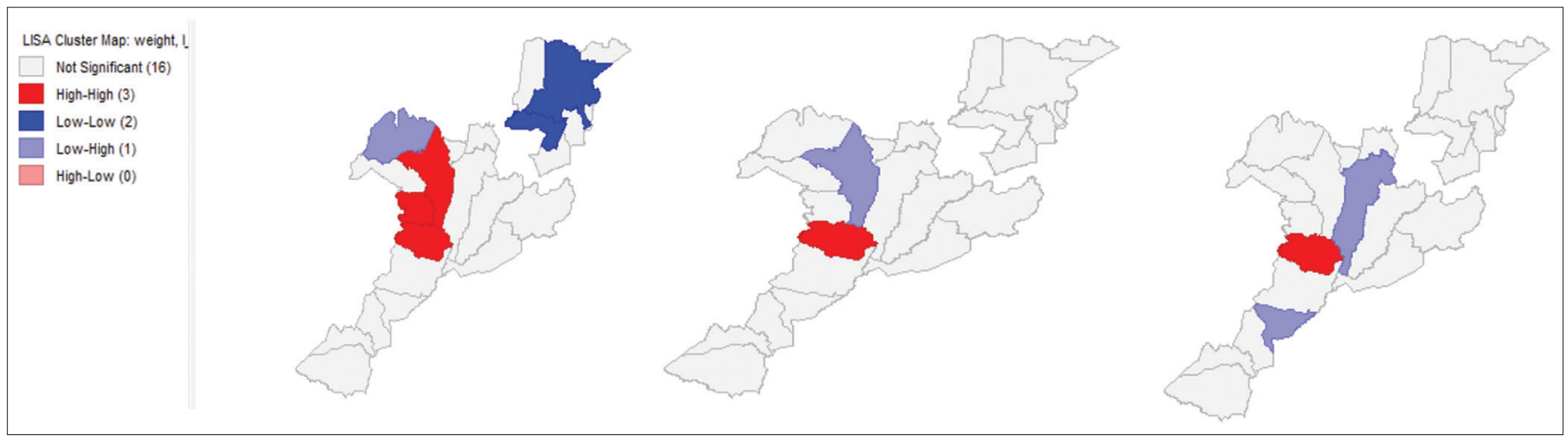

Figure 1: Local indicator spatial autocorrelation map of malaria case cluster in 2017-2019 in Muara Enim Regency 
autocorrelation, which means that malaria cases in 2019 occurred randomly or spread.

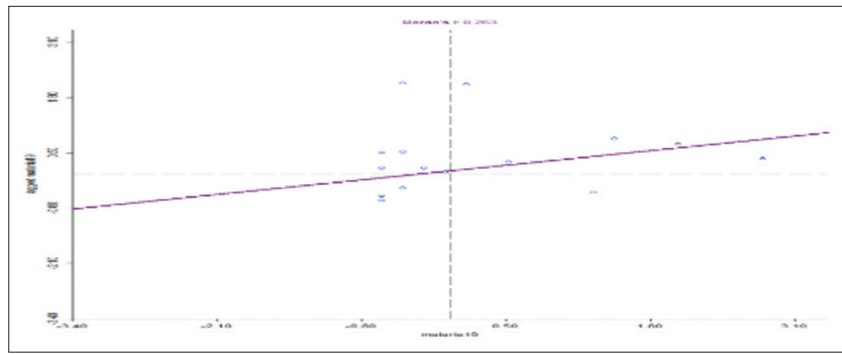

Figure 2: Moran index of malaria case in Muara Enim in 2017

Based on the analysis results of Moran and LISA that the area with the highest vulnerability for the past 4 years is Lawang Kidul area because it belongs to quadrant $1(\mathrm{HH})$ area, which is an area with high cases surrounded by areas that also have high cases for the past 3 years.

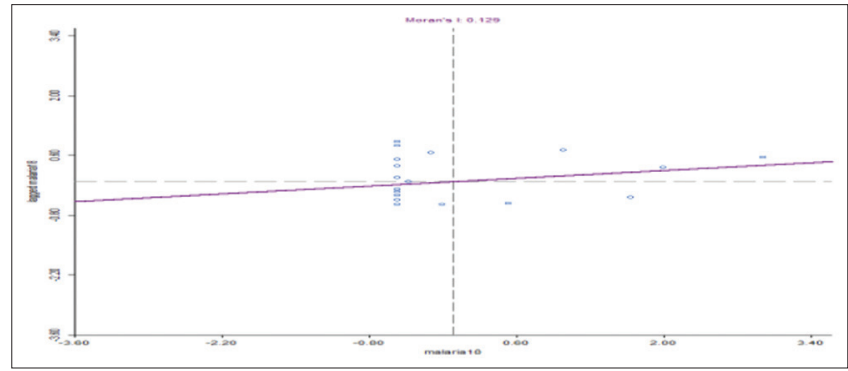

Figure 3: Moran index of malaria case in Muara Enim in 2018

\section{Identification and analysis of changes} in spatial patterns of environmental variability (rainfall) and density in Muara Enim Regency using Moran index and LISA

Based on the analysis results of Figure 5, there are three areas in Muara Enim Regency that have a spatial pattern on the population density variable. Districts belong to $\mathrm{HH}$ category (quadrant 1) are Sungai Rotan District, while districts belong to the LH category (quadrant 2) are Rambang and Empat Petulai Dangku Districts.

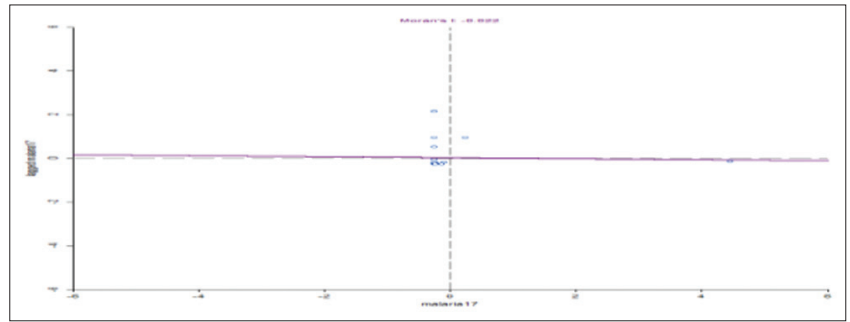

Figure 4: Moran index of malaria case in Muara Enim in 2019

Based on Figure 6, the density distribution has a moral value of 0.062 , has a positive but low autocorrelation, and only some areas have a density pattern.

Based on the analysis results shown in Figure 7, there are four areas in Muara Enim Regency that have a spatial pattern on the rainfall variable, in which the districts belong to the LL category

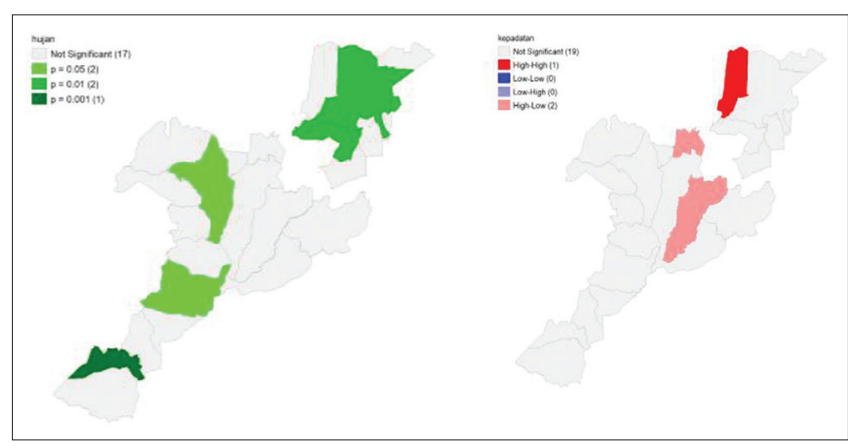

Figure 5: Local indicator spatial autocorrelation analysis of rainfall and density variable

(quadrant 3), which is Gelumbang District. Meanwhile, the districts classified as LH (quadrant 2) are Gunung Megang, Tanjung Agung, and Semende Darat Tengah Districts.

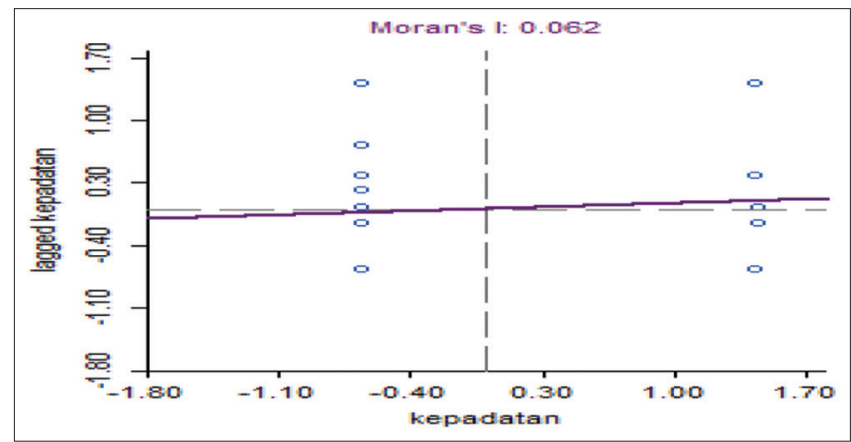

Figure 6: Moran index of rainfall and density variable

Based on Figure 8, there is a positive autocorrelation on the rainfall variable, thus the conclusion is that the rainfall in Muara Enim Regency forms clusters or groups.

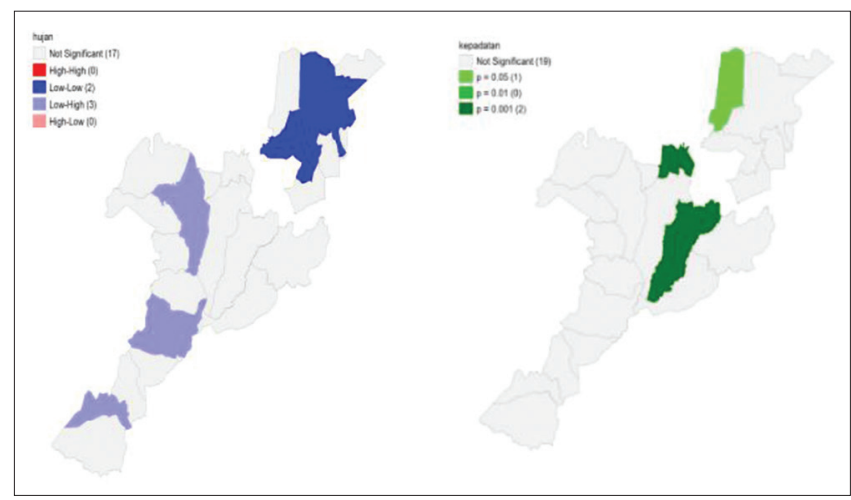

Figure 7: LISA analysis of rainfall and density variable

Identification and changes of spatial pattern of habitat in Muara Enim Regency

Figure 9 shows that almost all areas have shrubs compared to other areas whose shrubs area does not really reach the entire boundary area.

Figure 10 shows area with the most lake, which is Gunung Kidul.

Based on Figure 11, not many ponds were found in the three highest subdistricts. This indicates 
that there was no correlation between the existence of ponds and the number of cases.

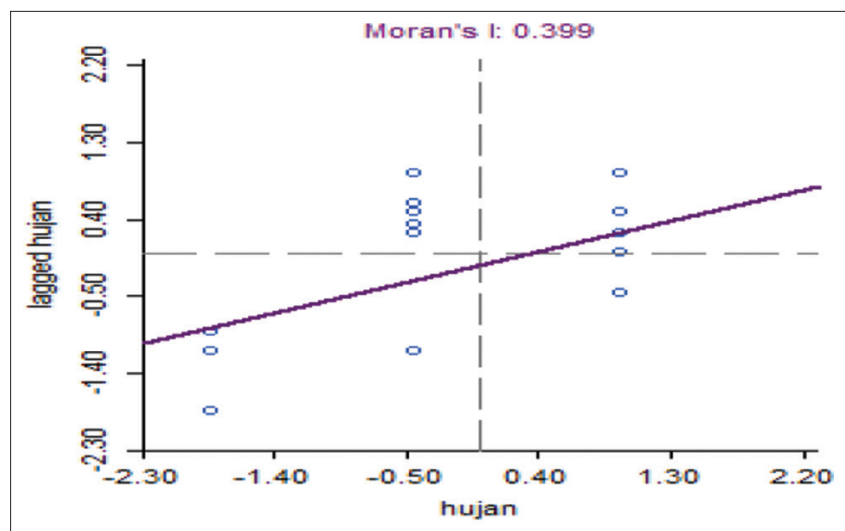

Figure 8: Moran index of rainfall and density variable

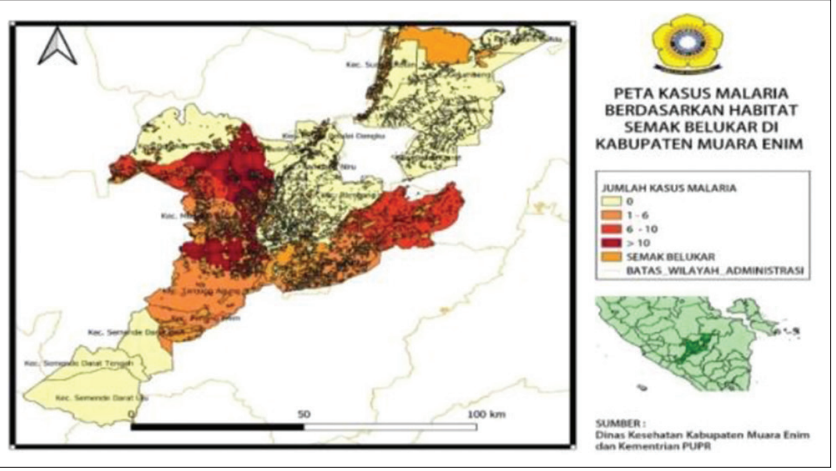

Figure 9: Map of malaria case based on shrubs habitat in Muara Enim Regency

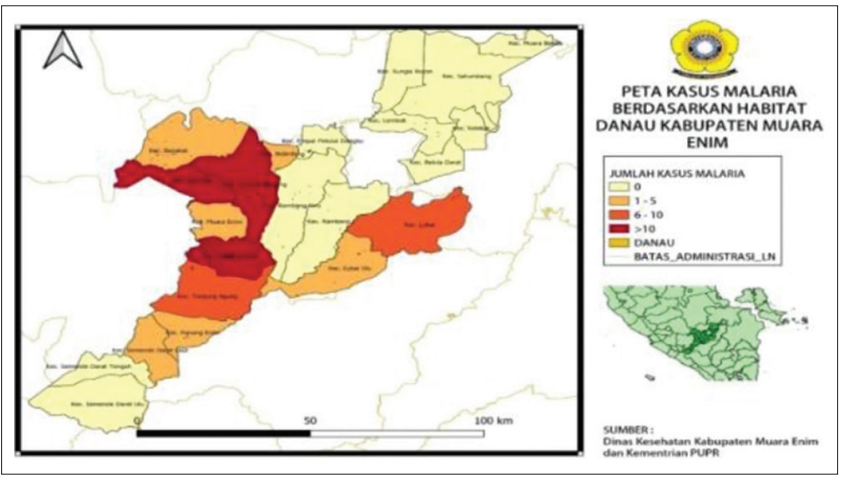

Figure 10: Map of malaria case based on Lake Habitat in Muara Enim Regency

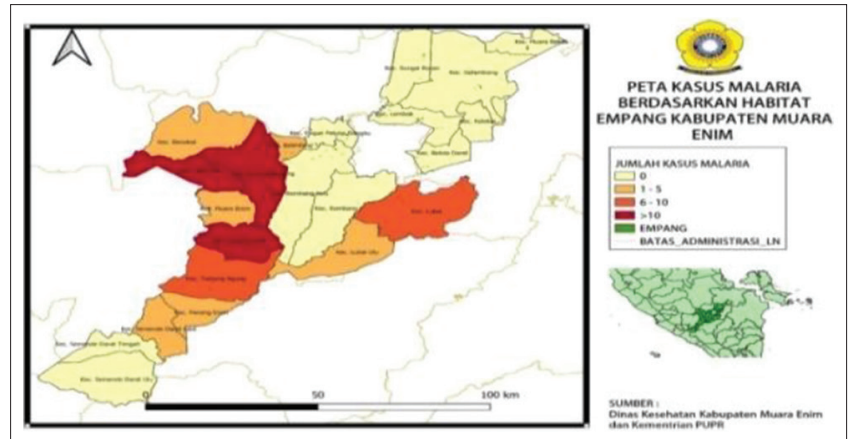

Figure 11: Map of malaria case based on pond habitat in Muara Enim Regency
Figure 12 presents that Lawang Kidul and Tanjung Agung areas have a quite large dry forest area.

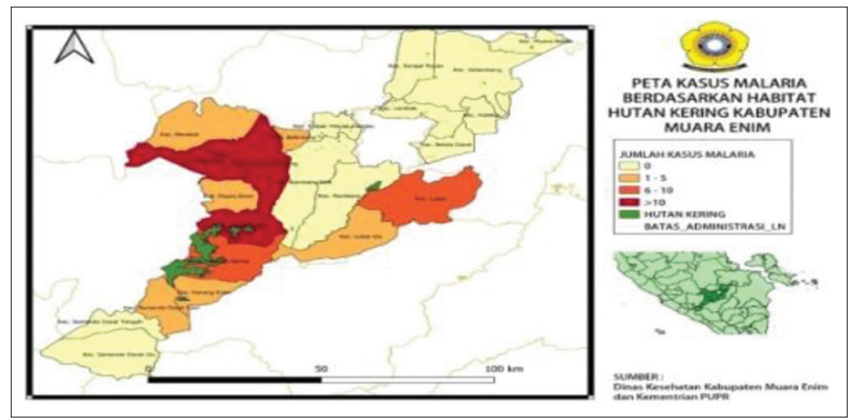

Figure 12: Map of malaria case based on dry forest habitat in Muara Enim Regency

Figure 13 shows that areas with the most garden are Panang Enim District.

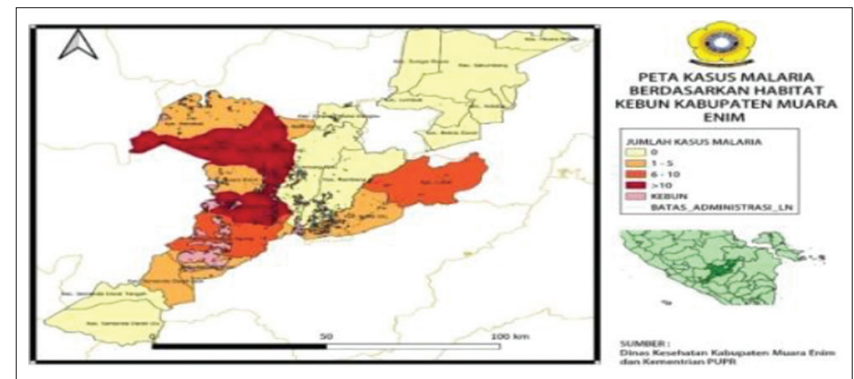

Figure 13: Map of malaria case based on garden habitat in Muara Enim Regency

Figure 14 shows that there is a quite a lot of swamps scattered in all three highest districts.

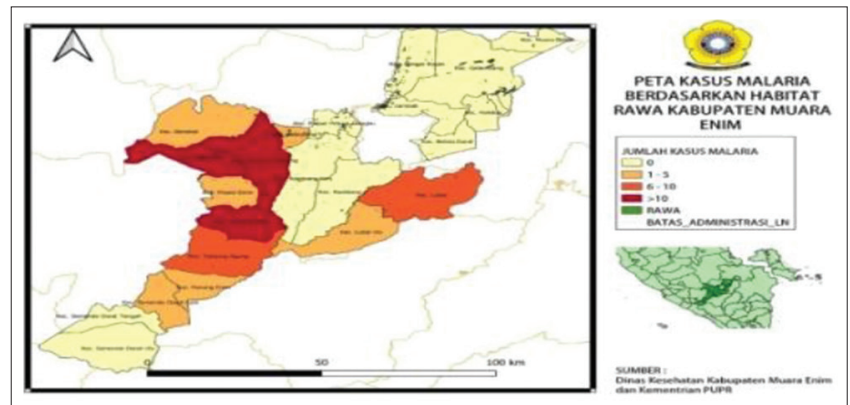

Figure 14: Map of malaria case based on swamp habitat in Muara Enim Regency

Based on Figure 15, it is known that the most farms habitats are located in Belida Darat and Sungai Rattan areas. In the three highest subdistricts, there are not many farms so that the correlation between rice fields and malaria cases was not subjectively found.

The conclusion based on the identification results and changes in spatial patterns on the map of malaria cases by habitat shows that changes in spatial patterns are found in the habitat of shrubs, lakes, dry forests, and swamps. 


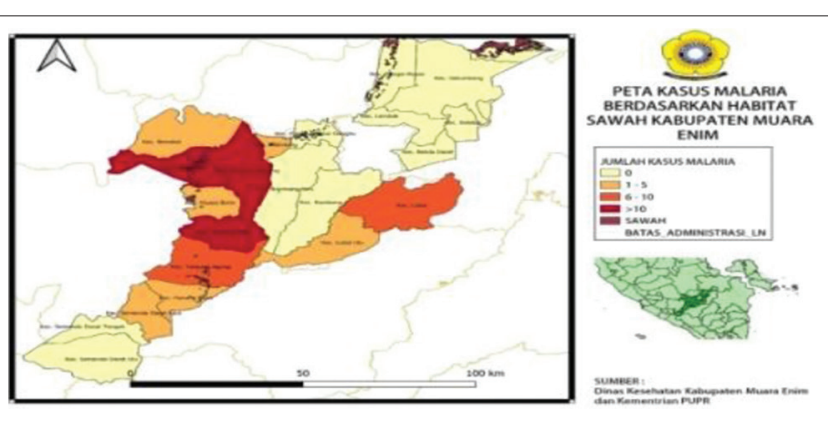

Figure 15: Map of malaria case based on farm habitat in Muara Enim Regency

Identification and change of spatial patterns of land use and altitude in Muara Enim Regency

Based on Figure 16, it is known that the three highest subdistricts are dominated by land use in the form of shrubs and smallholder plantations.

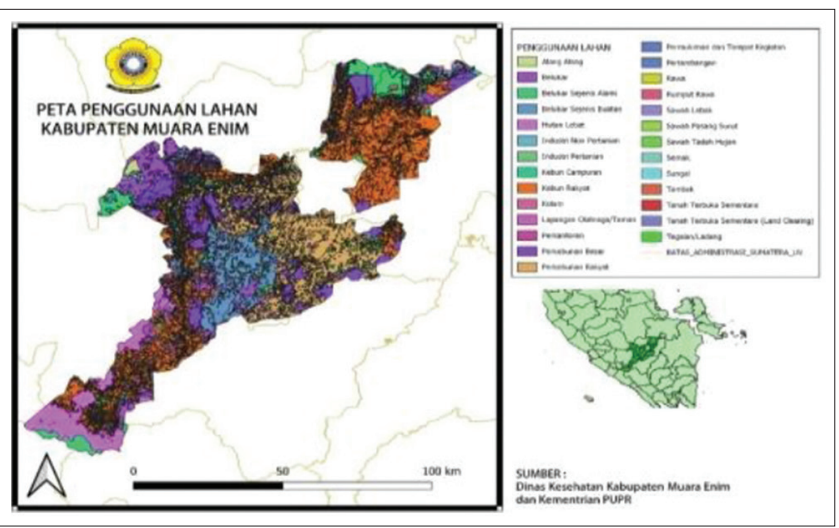

Figure 16: Map of spatial analysis of land use in Muara Enim Regency

Based on Figure 17, it is known that there is no detectable altitudein the northern region. Therefore, no relationship pattern found between the number of cases and the altitude.

\section{Discussion}

\section{Analysis of spatial patterns in Malaria cases in Muara Enim Regency using Moran index and LISA}

Moran and LISA analysis were performed on malaria cases in Muara Enim Regency in 2017-2019, discovering that Lawang Kidul is the area with the highest vulnerability for the past 3 years because it was included in quadrant 1 area $(\mathrm{HH})$, which is area with high cases surrounded by areas that also had high cases in the past 3 years. The spatial pattern of malaria spread in Muara Enim Regency in 2017 and 2018 occurred in groups with an index of 0.263 and 0.129 , while in 2019 , the spatial pattern of malaria spread changed to random or spread with a Moran index of -0.022 .

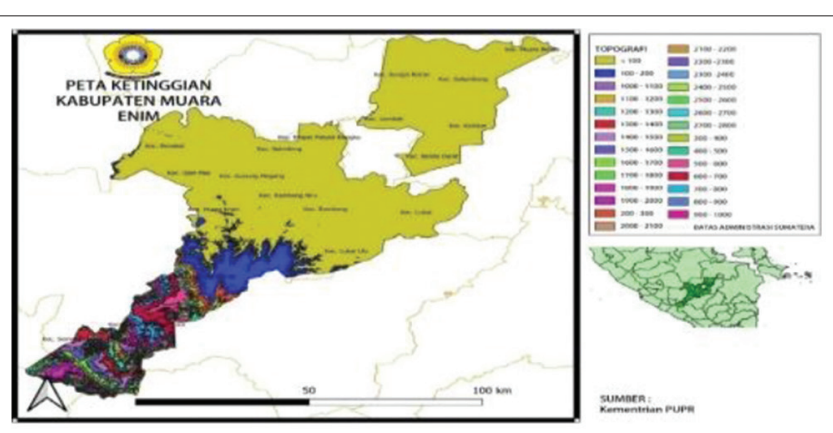

Figure 17: Map of altitude spatial analysis in Muara Enim Regency

Moran's Scatterplot indicated the relationship value between observations at a standardized location and the average value of observations at neighboring locations [9]. Moran's scatterplot is illustrated in the form of a scatterplot diagram consisting of four quadrants, in which each quadrant shows a spatial relationship pattern between locations, those are LL, LH, highlow $(\mathrm{HL})$, and $\mathrm{HH}$. LL indicates the location with an observation low value and is surrounded by locations with a high observation value, while LH indicates a location with a low observation value and is surrounded by locations with high observation value [5], [10].

Another previous research was carried out by Prahutama and Hoyyi (2016) concerning the spatial pattern of malaria spreads in Central Java from 2013 to 2015 which formed a clustered pattern for several regions. Based on the distribution pattern, the number of malaria sufferers from 2013 to 2015 decreased. There is a spatial autocorrelation of malaria spread in Central Java from 2013 to 2015. Meanwhile, regarding the factors affecting the spread pattern, only population density and the percentage of slum households have spatial autocorrelation [11].

Research that has been conducted previously by Barati et al. (2012) on the spatial analysis of malaria transfer in Iran obtained that the spread of malaria in Iran borders with the southeastern regions including Kerman, Hormozgan, and Sistan-Baluchestan regions [12]. It can be concluded that Moran and LISA analysis shows that areas with the highest vulnerability will cause various patterns of spread of malaria.

\section{Identification and analysis of changes in spatial patterns of environmental variability (rainfall) and density in Muara Enim Regency using Moran index and LISA}

The Moran and LISA analysis results of environmental variability (rainfall) in Muara Enim Regency showed a positive autocorrelation forming clusters or groups. There were four areas that have a spatial pattern, one area with low rainfall (LL) which is Gelumbang, and three subdistricts with high rainfall, which are Gunung Megang, Tanjung Agung, and Semende Darat Tengah. Regarding the density variability, there were three districts which have a 
spatial pattern, one area with a high population density surrounded by areas with a high population density $(\mathrm{HH})$ which is Sungai Rotan subdistrict and two areas with high population density surrounded by areas with a low population density (HL), which are Rambang Dangku and Empat Petulai Dangku, with a Moran value of 0.062 . This value indicated a positive but low autocorrelation because only part of the area had a density pattern.

This study is in accordance with the results of research conducted by Prahutama and Hoyyi (2016)[11] which obtained that population density affects the spread of malaria in Central Java in 20132015 with a Moran value of -0.6168 indicating an autospatial correlation, while regarding the rainfall, according to Suryaningtyas et al. [13], spatial pattern of malaria cases spread over all altitudes with the highest case was at an altitude of 500-1000 mdpl with rainfall $>200 \mathrm{~mm}$ (wet month) and high rainy days. Therefore, vigilance needs to be increased by observing rainfall, humidity, and temperature on a weekly scale in collaboration with BMKG.

Furthermore, a study performed by Narulita from the Geotechnology Research Center of LIPI in 2016 found that the monthly and annual spatial distribution of rainfall in Cerucuk watershed was affected by topography. The rainfall cycle showed an equatorial type, where the peak of rainfall occurs twice a year in April and December [14].

Another research carried out by Pravitasari and Hakim (2016) was also conducted using the K-Means cluster, obtaining that Group 1 was a medium endemic area, Group 2 was a low endemic area, and Group 3 was a high endemic area with an F-measure cluster validation value of $93.75 \%$. For spatial autocorrelation through statistical testing, the Zcount value was 2,309, which means that malaria cases do not occur randomly, in other words, there is an effect of proximity between locations on the number of malaria cases that occur [15].

In addition, research conducted by Suryaningtyas et al. in 2012 on the Spatial Statistics of Population Density of Malaria Incidence in Purworejo Regency Using GIS further found that there was no significant relationship between population density and malaria incidence in Purworejo Regency (spatial statistics) [13]. This research can be summed up that there was a spatial pattern change in Muara Enim Regency which was affected by rainfall and density.

\section{Identification and changes of spatial pattern in habitat in Muara Enim Regency}

Current research obtained that habitat spatial analysis results revealed that there were three highest subdistricts (Lawang Kidul, Tanjung Agung, and Gunung Megang subdistricts). It was known that almost all of these areas have shrubs compared to other areas whose shrubs do not really reach all boundaries. Meanwhile, regarding the lake habitat, the region with the most lake area is Lawang Kidul area. Furthermore, concerning the pond habitat, not many pounds were found in the three highest subdistricts. This shows that there was no correlation between the presence of ponds and the number of malaria cases. Based on the dry forest habitat, it was known that Lawang Kidul and Tanjung Agung have a large area of dry forest. Based on the farm habitat, it was known that most of the orchard are in Panang Enim Subdistrict. In the three highest subdistricts, there are orchards that are not too large. Thus, there was no correlation between the existence of the farm and the number of cases. Based on the farm habitat, it was obtained that there was quite a lot of farm spread in all three highest subdistricts. Based on the farm habitat map, most of the farms are in Belida land area and Sungai Rotan. However, not many farms were found in the three highest subdistricts, therefore, there was no correlation between farms and malaria cases subjectively.

This study is in line with the research previously done by Laumalay et al. in 2019 regarding the spatial analysis of Anopheles habitat characteristics. It was revealed that the existence of Anopheles spp. larvae was affected by the type of breeding habitat, Anopheles sucking during the day, and the presence of plants in the breeding habitat. Four Anopheles barbirostris and A. subpictus are primary vectors of malaria in East Nusa Tenggara Province. Anopheles species have specific breeding habitats. Sometimes, two or more species are found in one breeding habitat, but certain species are only found in certain breeding habitats. A. barbirostris preferred certain breeding habitats such as water flow, tank boundaries, irrigation canals, farms, seepage areas, temporary ponds, standing water near the coast, standing water in rivers, springs, abandoned fish ponds, and swamps. Meanwhile, $A$. subpictus is more likely to choose the type of habitat for brackish water puddles among mangroves, fish ponds, and other brackish water bodies. Furthermore, nine Anopheles vagus were found in irrigation canals, farms, and drainage canals [16].

It can be summed up that habitat found in Muara Enim Regency is a breeding habitat for Anopheles mosquito. Based on the map, it shows that most farm habitat is in Belida land area and Sungai Rotan. In the three highest subdistricts, there are not many farms found. Therefore, there was no correlation between farms and malaria cases subjectively.

\section{Identification and changes of spatial pattern of land use and altitude in Muara Enim Regency}

Based on the results of this research, it was found that there were three highest subdistricts dominated by land use in the form of shrub, bush, and smallholder plantations. Meanwhile, according to the 
altitude map, it was found that no altitude was found in the northern region so that no pattern was found in the relationship between the number of cases and the altitude.

The results of previous research performed by Wigaty et al. obtained that regarding the Effect of Land Use Change on Malaria Disease Rates: A Study in Lampung Province. It was revealed that land use was very influential related to malaria cases. Furthermore, another research related to spatial analysis in land and elevation classification is very influential. The results of the study proved that changes in land use of mangrove forests and swamps cause ecological disturbances that affect morbidity [18]. Meanwhile, variables which did not significantly affect malaria morbidity are state forests, community forests, built-up land, dry land, other uses, population density, rainfall, unfit houses, and urbanism [17], [18].

\section{Conclusion}

The current research revealed that area in Muara Enim Regency which has the highest malaria cases is Lawang Kidul Region. Furthermore, in Muara Enim Regency, there is only part of it which has a density pattern, four areas that have spatial patterns on rainfall variables, it is a breeding place for Anopheles mosquitoes, has the three highest districts in land use, and no altitude detected in the northern region.

\section{Acknowledgment}

This research is part of the Dissertation research of the Doctoral Program in Environmental Sciences, Sriwijaya University. Therefore, the researcher would like to express gratitude for the assistance and support provided, particularly from the Chancellor, the Director of Postgraduate, and the Dean of the Faculty of Public Health, Sriwijaya University who have helped me to complete this dissertation.

\section{References}

1. Elyazar IR, Hay SI, Baird JK. Malaria distribution, prevalence, drug resistance and control in Indonesia. Adv Parasitol. 2011;74: 41-175. https://doi.org/10.1016/B978-0-12-385897-9.00002-1 PMid:21295677

2. Hasyim H, Camelia A, Fajar NA. Determinan kejadian malaria di wilayah endemis. Kesmas Natl Public Health J. 2014;291:367. https://doi.org/10.21109/kesmas.v0i0.367.

3. Maretasari G, Windusari Y, Lamin S, Hanum L, Septiawati D. Characteristics of habitat, distribution, and diversity of Anopheles Spp in kemelak bindung langit village, ogan komering ulu regency, South Sumatra.J Environ Sci Sustain Dev. 2019;2: 165-75. https://doi.org/10.7454/jessd.v2i2.1035

4. Coulibaly JT, N'Gbesso YK, Knopp S, N'Guessan NA, Silué KD, van Dam GJ, et al. Accuracy of urine circulating cathodic antigen test for the diagnosis of schistosoma mansoni in preschoolaged children before and after treatment. PLoS Negl Trop Dis. 2013;7(3):e2109. https://doi.org/10.1371/journal.pntd.0002109 PMid:23556011

5. McGarigal K, Cushman SA, Neel MC, Ene E. FRAGSTATS: Spatial Pattern Analysis Program for Categorical Maps. Analysis. 2002. Retrieved from http://www.umass.edu/landeco/ research/fragstats.html.

6. Cao J, Zhu J, Zhang Q, Wang K, Yang J, Wang Q. Modeling urban intersection form: Measurements, patterns, and distributions. Front Archit Res. 2021;10:33-49. https://doi. org/10.1016/j.foar.2020.11.003

7. Gemperli A, Vounatsou P, Kleinschmidt I, Bagayoko M, Lengeler C, Smith T. Spatial patterns of infant mortality in mali: The effect of malaria endemicity. Am J Epidemiol. 2004;159(1):64-72. https://doi.org/10.1093/aje/kwh001 PMid:14693661

8. Sunarsih E, Purba IG, Suheryanto S, Rosyada A, Razak R Septiawati D. Spatial Modeling of Environmental Sanitation as the Distribution Determinant of Malaria Cases in Lahat Regency. United States: $2^{\text {nd }}$ Sriwijaya International Conference on Public Health; 2020. https://doi.org/10.2991/ahsr.k.200612.023

9. Legendre P, Fortin MJ. Spatial Pattern and Ecological Analysis Vegetatio. 1989;80:107-138. https://doi.org/10.1109/34.824819

10. Jain AK, Duin RP, Mao J. Statistical Pattern Recognition:AReview. United States: IEEE Trans Pattern Anal Mach Intell; 2000. https://doi.org/10.1109/34.824819.

11. Prahutama A, Hoyyi A. Spatial pattern penyebaran malaria di Jawa Tengah. Statistika 2016;4:25.

12. Barati M, Keshavarz-Valian H, Habibi-Nokhandan M, Raeisi A Faraji L, Salahi-Moghaddam A. Spatial outline of malaria transmission in Iran. Asian Pac J Trop Med. 2012;5:789-95. https://doi.org/10.1016/s1995-7645(12)60145-x PMid:23043918

13. Suryaningtyas NH, Margarethy I, Salim M. Analisis data spasia malaria di kabupaten kulon progo Tahun 2017. Spirakel. 2019;11:63-71.

14. Narulita I. Distribusi spasial dan temporal curah hujan di das cerucuk, Pulau Belitung.J Ris Geol Dan Pertamb. 2016;26:141. https://doi.org/10.14203/risetgeotam2016.v26.194

15. Pravitasari D, Hakim RB. Analisis Cluster K-means Dan Autokorelasi Spasial Untuk Identifikasi Pola Penyebaran Kasus Malaria (Studi kasus : Kasus malaria di kabupaten Purworejo Tahun 2015. Berlin, Germany: ResearchGate; 2016. p. 848-53. https://doi.org/10.32832/hearty.v5i1.1051

16. Laumalay HM, Satoto TB, Fuad A. Analisis spasial karakteristik habitat perkembangbiakan Anopheles Spp di desa lifuleo kecamatan kupang barat. Bul Penelit Kesehat. 2019;47(3): 207-16. https://doi.org/10.22435/bpk.v47i3.1451

17. Wigaty L, Bakri S, Santoso T, Wulan SR, Wardani D. Pengaruh perubahan penggunaan lahan terhadap angka kesakitan malaria: Studi Di Provinsi Lampung.J Sylva Lestari. 2016;4:1. https://doi.org/10.23960/jsl341-10

18. Anasiru RH. Spatial analysis in the classification of critica land in the sub-basin of Langge Gorontalo. Inform Pertan. 2016;25:261-72. 